\title{
OSBPL10 Gene
}

National Cancer Institute

\section{Source}

National Cancer Institute. OSBPL10 Gene. NCI Thesaurus. Code C148554.

This gene plays a role in binding to cholesterol and acidic phospholipids. 